\title{
Factors Associated with Schistosomiasis Mansoni in a Population from the Municipality of Jaboticatubas, State of Minas Gerais, Brazil
}

\author{
Cristiano Lara Massara/ ${ }^{+}$, Sérgio Viana Peixoto**, Héliton da Silva Barros*, \\ Martin Johannes Enk*, O mar dos Santos Carvalho, Virgínia Schall*
}

\author{
Laboratório de Helmintoses Intestinais *Laboratório de Educação em Saúde **Laboratório de Epidemiologia e Antropologia \\ Médica, Centro de Pesquisas René Rachou-Fiocruz, Av. Augusto de Lima 1715, 30190-002 Belo Horizonte, MG, Brasil
}

\begin{abstract}
Jaboticatubas is a municipality in the metropolitan region of Belo Horizonte which has been a target of a wide media release as "the capital of schistosomiasis" since the 1960's. In order to give support to a work based on an integrated control, we sought to identify the disease determinants at the site. A transversal study was carried out aimed at identifying prevalence rates of the disease and factors associated with the infection in the district of São José de Almeida, and two close localities, Cipó Velho and São José da Serra, all of them located in the municipality of Jaboticatubas. A parasitological survey was performed, applying the Kato-Katz method with two slides per sample in 1186 schoolchildren which represents $77 \%$ of all registered pupils in four public schools in 2001. Among these schoolchildren a number of 101 (8.6\%) prooved positive for Schistosoma mansoni eggs in their stool samples. A total of 64 families, whose schoolchildren had shown to be positive for schistosomiasis, also undertook examinations. As negative control, a random sample was collected from the 206 families, whose children had proven negative for schistosomiasis. The prevalence among 270 families (1304 people) was 12\%. To assess those who continued to have contact with possibly contaminated water, 1061 (81.4\%) people of the 270 families were interviewed. A multivariate analysis identified the following factors associated with the infection: time of residence in the area (short period), garbage disposal (use of deserted areas), gender (male), age (from 10 to 29 years), and water contact (daily and weekly). Further analysis of these factors revealed a close correlation between water contact and the disease, with a positive significant frequency concerning almost all those items. Depending on gender and age significant variations of water contact patterns associated with leisure and professional activities were found. A malacological survey on water collections in the area identified snails of the species Biomphalaria straminea and B. glabrata. The latter showed $17(0.6 \%)$ specimens positive for $\mathrm{S}$. mansoni. Qualitative studies have complemented such evidences, which allowed us to design a reference picture and specific indicators of the disease for the local population. Those data provided the essential information to continue the development of an already ongoing educative process, as well as projects on environmental improvements.
\end{abstract}

Key words: schistosomiasis - schoolchildren - Minas Gerais - Brazil

Socio-demographic variables and outdoor activities associated with water contact have always been associated with Schistosoma mansoni infection.

Several studies have been carried out in order to evaluate such association in endemic areas (Lima e Costa 1983, Silva et al. 1997, Barbosa \& Barbosa 1998, Moza et al. 1998, Bethony et al. 2001, 2004). In Brazil, Lima e Costa (1983) have reported that the water used for agricultural purposes showed to be a factor closely associated with $S$. mansoni infection in schoolchildren, while Guimarães et al. (1985) have shown that water contact in household activities were associated with the infection in people aged less than 15 years old.

Financial support: Fundação de Amparo a Pesquisa de Minas, $\mathrm{CNPq}$

${ }^{+}$Corresponding author. Fax: +55-31-3295.31.15. E-mail: massara@cpqrr.fiocruz.br

Received 28 May 2004

Accepted 26 July 2004
According to Cairncross et al. (1996) and Watts et al. (1998), an important characteristic for schistosomiasis transmission is a set of household activities related with water use. Such activities may be related with infection foci leading to the spread of risk factors for the family members.

Socio-economical status and its correlation with schistosomiasis has also been extensively studied in several countries worldwide (Lima e Costa 1983, Husting 1983, Bethony et al. 2004). However, knowledge on specific, local features of water contact that determine schistosomiasis infection, as well as the representation local populations have regarding the disease are essential to provide support to elaborate control strategies, involving local communities (Barbosa et al. 1996). Seeking such conditional characteristics has a social meaning as it allows investigators to realize local people behavior, enabling an association between the disease and activities that may result in increasing risk factors in order to propose specific prevention strategies (Laurel \& Gil 1975).

The present article discusses some of the epidemiological aspects of schistosomiasis in the town of São José de Almeida and in other two localities of the municipality 
of Jaboticatubas: São José da Serra and Cipó Velho. There have been records on the disease in this municipality since 1948, when Pellon and Teixeira (1950) performed a parasitological survey in the area and found a prevalence of $35.7 \%$.

Surveys using stool examinations carried out by the National Health Foundation (Funasa) and other researchers in this area, allowed us to understand the evolution of the prevalence in this municipality, which ranged from 15.4 to $48.6 \%$ throughout the time and in different localities (Brener \& Mourão 1956, Souza et al. 1988, Cury et al. 1994).

Malacological surveys performed by Ruiz (1952), Melo and Pereira (1985), Souza et al. (1998) and Massara et al. (2002) in this municipality have shown the presence of three snail species, which are $S$. mansoni transmitters.

Since 1986, Funasa has been undertaking malacological surveys, parasitological inquiries, and treatments of the disease. Infection levels nowadays remain between 15 and 25\% (regional reports from Jaboticatubas)

The present study was designed to describe the prevalence of schistosomiasis in schoolchildren and their families, diagnosing factors associated with the infection, in order to develop an integrated control program including the participation of schools (teachers and students), families and local health and education authorities.

\section{MATERIALS AND METHODS}

Study area - The municipality of Jaboticatubas is located in the metropolitan region of Belo Horizonte, capital of the state of Minas Gerais, in the microregion of Sete Lagoas. The extension of Jaboticatubas is $1113 \mathrm{~km}^{2}$ and it is $64 \mathrm{~km}$ distant from Belo Horizonte (Fig. 1), with a population of 13,530 inhabitants (IBGE 2000), from which a number of $7116(52.6 \%)$ are distributed in the urban area and $6414(47.4 \%)$ in rural area. The local economy is based on agriculture and cattle breeding.

Our study was conducted between 2001 and 2003. The town of São José de Almeida and the localities, São José da Serra, and Cipó Velho, are in the north of Jaboticatubas.

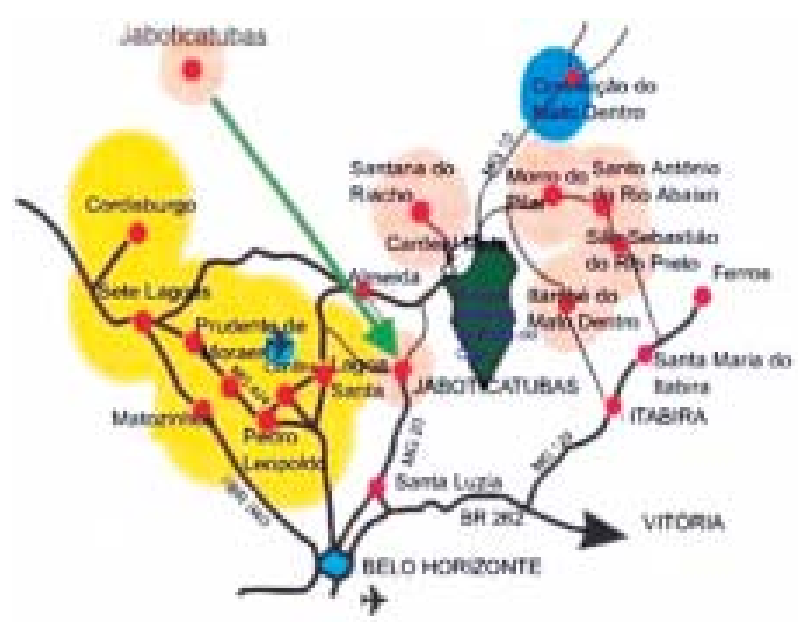

Fig. 1: localization of the municipality of Jaboticatubas in relation to Belo Horizonte, Minas Gerais, Brazil, and cities of the metropolitan region
The access road is MG 010, also used by tourists who visit Parque Nacional da Serra do Cipó (National Park of Serra do Cipó).

Considering populational and geographical features of Jaboticatubas, such as an abundant presence of waterfalls, rivers and streams crossing populational rural areas without basic sanitation, and a schistosomiasis prevalence rate of $33.52 \%$, recorded in 1976, Funasa included this municipality in the Special Control Program of Schistosomiasis (Pece) (CDS 1976).

Study population and selection of cases and controls - An inquiry was conducted in four public schools: two in the town of São José de Almeida - Escola Estadual Doutor Eduardo Góes Filho and Escola Municipal Paulo Rodrigues de Aguilar, one in the locality of São José da Serra - Escola Municipal Benfica Moreira Marques and another in Cipó Velho - Escola Municipal Padre Candinho. Inclusion criteria were based on Funasa reports (regional of Jaboticatubas), according to which positive snails and high $S$. mansoni prevalence rates were found. Those schools serve residents from several localities from the municipality, in a system named centralization.

The four schools enrolled a total of 1533 students in 2001. To each student, after an explanation of the purpose of the present project, a stool collection glass was given, labeled with the following information: student name, registration number, year at school, and the teacher's name. After collection, the flasks were given to the teachers, up to three days after our order, and then sent to the laboratory to be processed and examined. Based on results, positive schistosomiasis schoolchildren and a random negative sample (control group) were selected. Their residences were also visited and the whole families participated in our project, providing stool to undergo parasitological examinations. These flasks were also sent to the schools with personal identification in a plastic bag and a reference of the related student.

A total of 270 residences were visited. In 64 of them schoolchildren positive for schistosomiasis were identified.

Stool examination - Parasitological diagnosis was carried out through the quantitative method Kato-Katz (Katz et al. 1972). Two slides of each stool sample were examined. The quantitative exam was only performed for $S$. mansoni, and the arithmetic average of eggs per slide was calculated.

The slides were read by a technician from the Laboratory of Intestinal Helminthiasis at Centro de Pesquisas René Rachou-Fiocruz (Oswaldo Cruz Foundation), who has more than 25 years experience in coproscopical examinations.

Foci of transmission - An experienced technician, in the presence of research team, performed the collection of the snails at streams, lakes, dams, rivers, and irrigation wells in the study area. The process was carried out with a metal shell and tweezers and the snails were then placed in plastic bags and sent to the laboratory. After being measured, the snails were exposed to artificial light for approximately $1 \mathrm{~h}$ in order to have their examination for the presence of $S$. mansoni, under a stereomicroscope. Following, the snails were smashed between two glass 
slides in order to verify the presence of $S$. mansoni cercariae or sporocyst. A snail sample was separated and identified by both morphological, according to Paraense (1975) and molecular means (Vidigal et al. 1998), described by Massara et al. (2002).

Interview on water contact and socio-demographic survey - Interviews were carried out in all residences visited. After signing a consent term, an representative of the household was questioned. All information was collected by previously trained members of the research team applying a semi-structured questionnaire. This questionnaire characterized by socio-economical and sanitation conditions, including four categories of variables: (a) $d e$ mographic: name, address, age, gender, residential status, period of residence in the area, and family origin; (b) socio-economical: presence of electric energy, water filter, household utilities (radio, fridge, television), monthly income, education, structural condition and quality of the houses and number of people living within the residence; (c) sanitation: garbage disposal, presence of water treatment and; (d) contact with possibly contaminated water due to leisure, occupation or other activities.

To assess the structural condition and quality of the houses, values were attributed to the materials used for their construction, according to Lima and Costa (1983), with some modifications. Houses scored 32 or higher (3rd quarter) were classified the best quality; those scored between 23 and 31 , were classified as intermediate quality and those scored 22 or less, lower quality (1st quarter).

Interviews on water contact were carried out with all participants of this study by the same interviewers, who questioned the representative of each household. Information was given by each subject, helped by their mothers or the responsible when they were less than 10 years old. Only contacts with water within the municipality of Jaboticatubas were considered in this study.

Frequency of water contact was evaluated, regarding the most common activities in their communities, such as: washing clothes, fetching water, taking baths, swimming, fishing, crossing the river, watering vegetable cultivation and working in agriculture areas, and sand extraction.

Analysis - Data analysis was based on Qui-square test to assess linear tendency and compare proportions. The $\mathrm{t}$ student test was used to compare averages.

Multiple logistic regression was used to determine independent effects on associations between $S$. mansoni infections and explanatory variables, estimating adjusted odds ratio and confidence intervals (95\%). In the initial logistic model, all variables associated with the infections in univariate analysis were included, with $p<0.20$. Variables with statistically significant associations $(\mathrm{p}<0.05)$ with $S$. mansoni infection were kept in the final model.

Analyses were performed using the software Epi Info 6.04 (Dean et al. 1990) and Stata (Stata Corporation 2001).

\section{RESULTS}

Stool examination - Results of parasitological examinations are shown in Table I. Out of 1,533 schoolchildren, $1186(77.0 \%)$ undertook parasitological surveys, from which 101 (8.6\%) showed to be positive for schistosomiasis. Out of those 101, three moved and one denied con- tinuing in our study. Among the helminthic diseases investigated, schistosomiasis showed the highest prevalence $(8.6 \%)$ with a geometric mean egg count per gram of stool of $50.67(\mathrm{dp}=3.70)$. For other parasites, low prevalence rates were found: $0.1 \%$ for Hymenolepis nana and $4.2 \%$ for Ascaris lumbricoides.

\section{TABLE I}

Prevalence of intestinal helminths in schoolchildren in four selected schools - District of São José de Almeida and two close localities - São José da Serra and Cipó Velho, municipality of Jaboticatubas, Minas Gerais, Brazil - 2001

\begin{tabular}{lrc}
\hline Schoolchildren & $\mathrm{Nr}$ & $\%$ \\
\hline Registered & 1533 & 100 \\
Examined & 1186 & 77 \\
Negatives & 971 & 82.3 \\
Positives & 209 & 17.7 \\
Schistosoma mansoni & 101 & 8.6 \\
Ascaris lumbricoides & 50 & 4.2 \\
Trichuris trichiura & 21 & 1.8 \\
Hookworm & 25 & 2.1 \\
Enterobius vermicularis & 31 & 2.6 \\
Himenolepis nana & 1 & 0.1 \\
\hline
\end{tabular}

Table II shows results from stool samples selected for a parasitological examination. Among them, prevalence of schoolchildren with schistosomiasis was $15.6 \%$, whereas their relatives showed a prevalence of $10.2 \%$.

Geometric mean of the egg count per gram of stool in schoolchildren was $61.23(\mathrm{dp}=3.69)$ and $45.08(\mathrm{dp}=3.98)$ in their relatives $(p=0.166)$.

For other parasitic diseases found, prevalence showed to be low ranging from $0.6 \%$ for Trichuris trichiura to $1.8 \%$ for A. lumbricoides among schoolchildren and from $0.3 \%$ for Enterobius vermicularis to $4 \%$ for hookworm among their relatives.

For all participants - schoolchildren and their relatives living in the same household - the prevalence of schistosomiasis was $12 \%$ with a geometric mean of the egg count per gram of stool of $54.45(\mathrm{dp}=3.83)$. For other parasites, prevalence rates ranged from $0.6 \%$ for $T$. trichiura to $2.5 \%$ for hookworm (Table II).

Fig. 2 shows schistosomiasis prevalence according to age and gender. The highest prevalence was observed in subjects aged from 10 to 19 and men.

Social demographic survey and water contact interview - Brazilian minimum monthly wage is US\$ 80 . In our study, $31.1 \%$ of the families earned a monthly income lower than that value. The socio-demographic survey revealed that only $39.4 \%$ of the residences had water treatment, $16.7 \%$ had no sanitary facilities, and garbage was thrown in deserted peridomiciliary areas. Considering the other variables that mirrored quality of life of the subjects under study, $88.8 \%$ had water filters, $86.6 \%$ had electric energy and $73.2 \%$ of the families had more than two household devices (radio, fridge, television). 
TABLE II

Prevalence of intestinal helminths in selected schoolchildren and their relatives - District of São José de Almeida and two close localities - São José da Serra e Cipó Velho, municipality of Jaboticatubas, Minas Gerais, Brazil - 2001

\begin{tabular}{|c|c|c|c|c|c|c|}
\hline & \multicolumn{2}{|c|}{ Schoolchildren } & \multicolumn{2}{|c|}{ Relatives } & \multicolumn{2}{|c|}{ Total } \\
\hline & $\mathrm{Nr}$ & $\%$ & $\mathrm{Nr}$ & $\%$ & $\mathrm{Nr}$ & $\%$ \\
\hline Registered & 642 & 100 & 773 & 100 & 1415 & 100 \\
\hline Examined & 621 & 96.7 & 683 & 87.2 & 1304 & 92.1 \\
\hline Negatives & 502 & 80.8 & 587 & 85.9 & 1089 & 83.5 \\
\hline Positives & 119 & 19.2 & 96 & 14.1 & 215 & 16.5 \\
\hline Schistosoma mansoni & 97 & 15.6 & 60 & 10.2 & 157 & 12 \\
\hline Ascaris lumbricoides & 11 & 1.8 & 16 & 2.7 & 27 & 2 \\
\hline Trichuris trichiura & 4 & 0.6 & 4 & 0.7 & 8 & 0.6 \\
\hline Hookworm & 9 & 1.4 & 24 & 4 & 33 & 2.5 \\
\hline Enterobius vermicularis & 9 & 1.4 & 2 & 0.3 & 11 & 0.8 \\
\hline
\end{tabular}

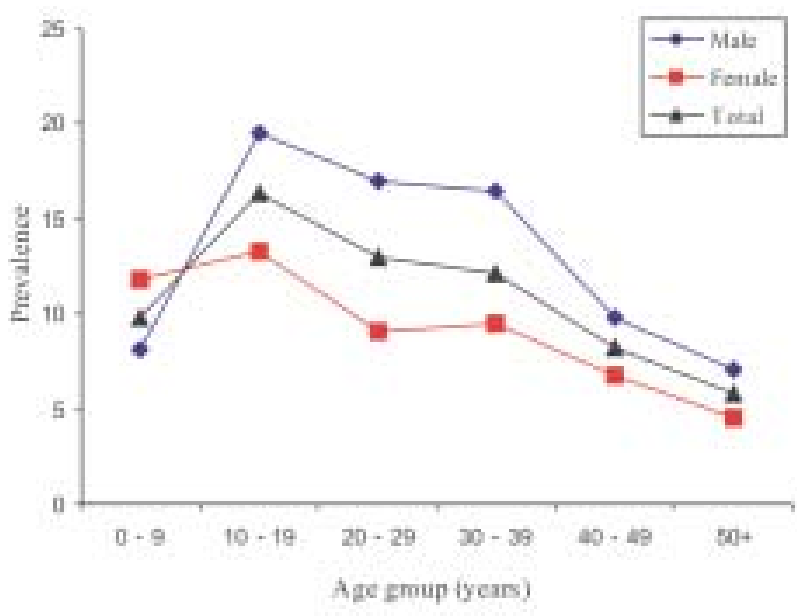

Fig. 2: prevalence of schistosomiasis mansoni, according to age group and gender, Jaboticatubas, Minas Gerais, Brazil - 2001

Retired people, housekeepers, schoolchildren and unemployed subjects comprised $64.1 \%$ of the population under study, followed by rural workers $(14.7 \%)$, unqualified workers $(11.8 \%)$, qualified workers $(7.1 \%)$ and rural land owners and traders $(2.3 \%)$.

Some of the above mentioned socio-economical conditions are the basis for the continuing transmission of schistosomiasis in the municipality.

Table III shows a distribution of reasons and frequency of water contact correlated with $S$. mansoni infection in $1061(81.4 \%)$ interviewed subjects. The activities of taking bath, fishing, crossing the streams, working in agriculture areas, watering vegetable plantations, and working in sand extraction, showed to be a statistically associated with infection $(\mathrm{p}<0.05)$.

In Table IV, the different reasons of water contact related with gender and infection by S. mansoni are shown. The kind of water exposure differs according to the gender for few categories. The most mentioned activities reported by men, statistically associated with S. mansoni infection, were: swimming, fishing, crossing streams, having bath, working in agricultural areas, and working in sand extraction. Women, otherwise, have reported: swim-
TABLE III

Distribution of Schistosoma mansoni infection according to water contact patterns in the studied population - District of São José de Almeida and two close localities - São José da Serra e Cipó Velho, municipality of Jaboticatubas, Minas Gerais, Brazil - 2001

\begin{tabular}{|c|c|c|}
\hline $\begin{array}{l}\text { Pattern of water } \\
\text { contact }\end{array}$ & $\begin{array}{c}\text { Negatives \% } \\
(\mathrm{N}=928)\end{array}$ & $\begin{array}{l}\text { Positives } \% \\
(\mathrm{~N}=133)\end{array}$ \\
\hline \multicolumn{3}{|c|}{ Contact for any reason } \\
\hline No & 19.4 & 1.5 \\
\hline Daily & 9.7 & 21.8 \\
\hline Weekly & 16.4 & 27.8 \\
\hline > Weekly & 54.5 & $\begin{array}{c}48.9 \\
\mathrm{p}<0.001\end{array}$ \\
\hline \multicolumn{3}{|l|}{ Washing clothes } \\
\hline No & 80.2 & 73.7 \\
\hline Daily & 7.6 & 12.8 \\
\hline Weekly & 9.5 & 11.3 \\
\hline > Weekly & 2.7 & $\begin{aligned} & 2.2 \\
p= & 0.189\end{aligned}$ \\
\hline \multicolumn{3}{|l|}{ Fetching water } \\
\hline No & 87.2 & 79.0 \\
\hline Daily & 8.6 & 15.0 \\
\hline Weekly & 2.5 & 4.5 \\
\hline > Weekly & 1.7 & $\begin{aligned} & 1.5 \\
\mathrm{p}= & 0.050\end{aligned}$ \\
\hline \multicolumn{3}{|l|}{ Having bath } \\
\hline No & 82.9 & 63.9 \\
\hline Daily & 7.5 & 23.3 \\
\hline Weekly & 5.5 & 6.0 \\
\hline$>$ Weekly & 4.1 & $\begin{array}{c}6.8 \\
p<0.001\end{array}$ \\
\hline \multicolumn{3}{|l|}{ Swimming } \\
\hline No & 41.5 & 19.5 \\
\hline Daily & 7.7 & 24.1 \\
\hline Weekly & 18.3 & 30.8 \\
\hline > Weekly & 32.4 & $\begin{array}{c}25.6 \\
\mathrm{p}<0.001\end{array}$ \\
\hline \multicolumn{3}{|l|}{ Fishing } \\
\hline No & 63.2 & 41.4 \\
\hline Daily & 3.2 & 16.5 \\
\hline Weekly & 6.3 & 15.8 \\
\hline > Weekly & 27.3 & $\begin{array}{c}26.3 \\
\mathrm{p}<0.001\end{array}$ \\
\hline
\end{tabular}




\begin{tabular}{lcc}
\hline $\begin{array}{l}\text { Pattern of water } \\
\text { contact }\end{array}$ & $\begin{array}{c}\text { Negatives } \% \\
(\mathrm{~N}=928)\end{array}$ & $\begin{array}{c}\text { Positives } \% \\
(\mathrm{~N}=133)\end{array}$ \\
\hline Crossing streams & & \\
No & 60.9 & 34.6 \\
Daily & 14.2 & 34.6 \\
Weekly & 7.1 & 20.3 \\
$>$ Weekly & 17.8 & 10.5 \\
& & $\mathrm{p}<0.001$ \\
Working in agricultural areas & & \\
No & 88.4 & 76.0 \\
Daily & 9.3 & 14.2 \\
Weekly & 1.5 & 6.8 \\
$>$ Weekly & 0.8 & 3.0 \\
& & $\mathrm{p}<0.001$ \\
Watering vegetable & & \\
No & 77.3 & 70.7 \\
Daily & 19.2 & 24.1 \\
Weekly & 3.1 & 3.0 \\
$>$ Weekly & 0.4 & 2.2 \\
& & $\mathrm{p}=0.047$ \\
Sand extraction & & \\
No & & \\
Daily & 98.3 & 91.7 \\
Weekly & 0.6 & 3.0 \\
$>$ Weekly & 0.0 & 0.8 \\
& 1.1 &
\end{tabular}

ming, crossing the streams, washing clothes, fishing, having bath, fetching water, and working in sand extraction. All of them were statistically associated with $S$. mansoni infection.

In Table $\mathrm{V}$, the different reasons of water contact related with age and infection by $S$. mansoni are shown. The data demonstrates a variation of the motives (specially in the order of priority) for water contact in different age groups. Between 0-9 years old, infection was associated in this order with (1) swimming, (2) crossing streams, (3) fishing, (4) having bath, (5) washing clothes, (6) fetching water, and (7) working in agricultural areas; between
10-19 years old, the activities associated with infection were (1) swimming, (2) fishing and crossing streams, (3) having bath, (4) working in agricultural areas, (5) fetching water (6), and working in sand extraction. In subjects aged over 20 years old the activities related with $S$. mansoni infection were: (1) crossing streams, (2) swimming, (3) fishing, (4) having bath, and (5) working in sand extraction.

Generally, it was observed that as age increases, activities related with agriculture and sand extraction elevate. Swimming predominance decreases according to age.

The initial logistic model included the following variables: time of residence in the area $(\mathrm{p}<0.01)$; residence status $(p=0.007)$; water origin $(p=0.009)$; type of canalization $(p=0.014)$; presence of water filter $(p=0.0593)$; source of energy used in the household (gas, electricity or wood $)(p=0.066)$; type of garbage disposal $(p<0.001)$; sanitary facilities $(\mathrm{p}=0.046)$; sewerage disposal $(\mathrm{p}=0.100)$; number of rooms in the houses $(p=0.047)$; household income $(\mathrm{p}=0.109)$; number of household devices $(\mathrm{p}=$ $0.084)$; structural quality of the houses $(\mathrm{p}=0.076)$; gender $(\mathrm{p}=0.067)$; education $(\mathrm{p}=0.005)$; age $(\mathrm{p}=0.007)$ and frequency of water contact for any of the reasons mentioned $(\mathrm{p}<0.001)$.

Results of the multivariate analysis of the relation between S. mansoni infection and socio-economical indicators are shown in Table VI. Factors associated with the infection were: time of residence in the area (shorter periods); garbage disposal (discharged in deserted peridomiciliary areas); gender (masculine); age (10-29); and water contact regardless frequency. The most relevant variable was daily, followed by weekly water contact.

Another logistic model was also built including the different reasons for water contact. Swimming, fishing, and crossing streams were statistically associated with $S$. mansoni infection $(\mathrm{p}<0.05)$.

Treatment - All schoolchildren and their relatives that showed some other parasitic disease were sent to the local health service support to undertake treatment with albendazole in a single dose. Positive schistosomiasis subjects were treated with oxamniquine or praziquantel, according to indications or availability of the drug.

\section{TABLE IV}

Reasons of water contact according to gender in relation to infection with Schistosoma mansoni in the studied population District of São José de Almeida and two close localities - São José da Serra e Cipó Velho, municipality of Jaboticatubas, Minas Gerais, Brazil - 2001

\begin{tabular}{|c|c|c|c|c|}
\hline \multirow[b]{2}{*}{ Reasons } & \multicolumn{2}{|c|}{ Male $\%$} & \multicolumn{2}{|c|}{ Female $\%$} \\
\hline & $\begin{array}{c}\text { Positive } \\
\mathrm{N}=72\end{array}$ & $\begin{array}{l}\text { Negative } \\
\mathrm{N}=394\end{array}$ & $\begin{array}{c}\text { Positive } \\
\mathrm{N}=61\end{array}$ & $\begin{array}{l}\text { Negative } \\
\mathrm{N}=534\end{array}$ \\
\hline Washing clothes & 6.9 & 8.1 & $49.2^{a}$ & 28.4 \\
\hline Fetching water & 12.5 & 8.4 & $31.1^{a}$ & 16.1 \\
\hline Having bath & $34.7^{a}$ & 20.8 & $37.7^{a}$ & 14.4 \\
\hline Swimming & $86.1^{a}$ & 72.1 & $73.3^{a}$ & 48.5 \\
\hline Fishing & $73.6^{a}$ & 54.5 & $40.9^{a}$ & 23.6 \\
\hline Crossing streams & $70.8^{a}$ & 43.0 & $59.0^{a}$ & 36.3 \\
\hline Working in Agricultural areas & $33.3^{a}$ & 14.9 & 13.3 & 9.2 \\
\hline Watering vegetable & 33.3 & 25.1 & 24.6 & 20.9 \\
\hline Sand extraction & $11.1^{a}$ & 3.0 & $4.9^{a}$ & 0.70 \\
\hline
\end{tabular}

$a: \mathrm{p}<0.05$ 
TABLE V

Reasons of water contact according to age groups in relation to infection with Schistosoma mansoni in the studied population District of São José de Almeida and two close localities - São José da Serra e Cipó Velho, municipality of Jaboticatubas, Minas Gerais, Brazil - 2001

\begin{tabular}{|c|c|c|c|c|c|c|}
\hline \multirow[b]{3}{*}{$\underline{\text { Reasons }}$} & \multicolumn{6}{|c|}{ Age (years) } \\
\hline & \multicolumn{2}{|c|}{$0-9$} & \multicolumn{2}{|c|}{$10-19$} & \multicolumn{2}{|c|}{$\geq 20$} \\
\hline & $\begin{array}{c}\text { Positive } \\
\mathrm{N}=21\end{array}$ & $\begin{array}{l}\text { Negative } \\
\mathrm{N}=192\end{array}$ & $\begin{array}{c}\text { Positive } \\
\mathrm{N}=68\end{array}$ & $\begin{array}{l}\text { Negative } \\
\mathrm{N}=346\end{array}$ & $\begin{array}{c}\text { Positive } \\
\mathrm{N}=44\end{array}$ & $\begin{array}{l}\text { Negative } \\
\mathrm{N}=381\end{array}$ \\
\hline Washing clothes & $28.5^{a}$ & 12.5 & 22.0 & 18.5 & 31.8 & 25.2 \\
\hline Fetching water & $23.8^{a}$ & 8.8 & $20.6^{a}$ & 10.4 & 20.4 & 17.3 \\
\hline Having bath & $47.6^{a}$ & 18.7 & $35.3^{a}$ & 15.3 & $31.8^{a}$ & 18.4 \\
\hline Swimming & $95.2^{a}$ & 75.5 & $89.7^{a}$ & 72.2 & $59.1^{a}$ & 38.3 \\
\hline Fishing & $57.1^{a}$ & 34.9 & $60.3^{a}$ & 41.8 & $56.8^{a}$ & 33.8 \\
\hline Crossing streams & $71.4^{a}$ & 34.9 & $60.3^{a}$ & 38.1 & $70.4^{a}$ & 42.7 \\
\hline Working in agricultural areas & $4.7^{a}$ & 0.0 & $26.5^{a}$ & 6.6 & 29.5 & 22.3 \\
\hline Watering vegetable & 14.3 & 11.5 & 27.9 & 21.7 & 38.6 & 29.6 \\
\hline Sand extraction & 0.0 & 0.0 & $5.9^{a}$ & 1.2 & $15.9^{a}$ & 3.1 \\
\hline
\end{tabular}

$a: \mathrm{p}<0.05$

\section{TABLE VI}

Multivariate analysis of the relation between Schistosoma mansoni infection and socio-economical indicators in the studied population - District of São José de Almeida and two close localities - São José da Serra e Cipó Velho, municipality of Jaboticatubas, Minas Gerais, Brazil - 2001

\begin{tabular}{lcc}
\hline Variables & Odds ratio & (IC $(95 \%)$ \\
\hline Time of residence in the area (years) & & \\
$>3$ & 1.0 & - \\
1 a 3 & 3.98 & $2.04-7.74$ \\
$<1$ & 2.36 & $1.13-4.92$ \\
Garbage disposal & & \\
Collected/burned/buried & 1.0 & - \\
Thrown away into deserted areas & 3.39 & $2.26-5.09$ \\
Gender & & \\
Female & 1.0 & \\
Male & 1.54 & $1.03-2.30$ \\
Age & & \\
$0-9$ & 1.0 & - \\
$10-19$ & 1.84 & $1.06-3.22$ \\
$20-29$ & 1.99 & $0.87-4.55$ \\
$30-39$ & 1.39 & $0.67-2.86$ \\
$40-49$ & 0.71 & $0.28-1.76$ \\
$\quad \geq 50$ & 0.53 & $0.18-31.59$ \\
Frequency of water contact & & \\
No & & \\
$>$ Weekly & 1.0 & - \\
Weekly & 8.63 & $2.06-36.30$ \\
Daily & 16.35 & $3.79-70.53$ \\
\hline
\end{tabular}

The analysis included 1058 participants; Odds ratio adjusted for all variables included into the Table.

Foci of transmission - A number of 2733 B. glabrata snails were collected in water collections in the area under study, from which 17 (0.6\%) showed to be positive for $S$. mansoni infection. Another species found was $B$. straminea, totaling 3841 specimens collected. All of them were negative for the presence of the trematode.
Out of 29 water collections explored in our study, three showed the presence of infected B. glabrata. Four specimens were collected in a stream in the area JK, close to the town of Almeida, three specimens were found in a farm stream, in the locality of Cipó Velho and 10 in the area Campo Grande. In 16 water collections, negative $B$. glabrata were found and in other 9 , no snails were found. In the stream São José, which crosses the town of São José de Almeida, only B. straminea snails were collected and reported for the first time in this region (Massara et al. 2002).

\section{DISCUSSION}

Results from the present study together with data from previous investigations (Massara et al. 2002, Diniz 2003, Massara \& Schall 2004) in the region have allowed us to design a diagnosis strategy for schistosomiasis in the area under study associated with further integrated control strategies for the disease.

Based on determining factors of the disease, according to Loureiro (1989), such as those related with bioecological, social, and cultural aspects, we have found a confluence of all of them in the region of Jaboticatubas. Concerning the bio-ecological aspect, favorable environmental conditions were detected for the vector reproduction (habitat) and parasite survival (stool pollution of water collections, proved by the proportion of $16.7 \%$ of houses, which had their stool residues thrown in deserted areas and streams among other situations). Moreover, environment has been extensively changed by the construction of artificial lakes, natural water pathways have been diverted for irrigation and agricultural purposes and natural streams that are crossed by tracks and roads. Such water contact is very clear when those local people were interviewed and they reported constant crossings, comprising the most common transmission via in adults.

Increasing rural tourism and leisure activities are also other factors that have changed local people behavior. Cultural aspects associated with schistosomiasis transmission were reported by Diniz (2003). Through a study on the social representation people had about schistoso- 
miasis, they showed poor scientific knowledge, wrong beliefs on the disease and confusion with other parasitic disorders. Furthermore, low parasitic rates as a consequence of successive treatments to prevent severe cases of the disease have also contributed to a passive behavior of those people concerning the disease, i.e., they admit the presence of infection as there is available treatment and cure. This situation contributes to prevent attitudes for environmental improvements.

The interviews with teachers from local schools and groups of people in the focus of transmission allowed us to reach important information on socio-economical facts and their history. Globalization of economy and sales of horticultural products by supermarket companies have discouraged small producers and farmers because of high mechanization of big investors in agriculture in other regions. Thus, tourism has been the most profitable activity in Jaboticatubas, requiring less man-power and decreasing the former demanding work force. On the other hand, this activity enables schistosomiasis transmission to other people classes, those who attend the area for tourism purposes, characterizing a new risk modality (Enk et al. 2003, 2004).

Migration has been also associated with the disease. Once the areas has required less workforce due to tourism activities, people have left the region leading to transmission to other areas, such as urban outskirts. Other people, even without a job, remain in the countryside leaving in substandard accommodations, being targets of malnutrition and diseases. As described here, this situation, which is a consequence of the development of the capitalist model, involves the whole social structure (Carvalheiro 1986), being reflected through the expansion of some endemic diseases and changes of the target population's profile.

The results from the current study allowed us to observe a wide range of factors and variables involved with schistosomiasis transmission in Jaboticatubas. Control strategies of the disease should contemplate all of those variable conditions both in economical activities and in cultural behavior.

However, some progress must be pointed out, as prevalence rates of schistosomiasis has dropped, including other parasitic diseases. According to our results, parasitological examinations have revealed low parasitic rates, differently from previous investigations carried out in the region (Pellon \& Teixeira 1950, Brener \& Mourão 1956, Souza et al. 1988, Cury et al. 1994). By comparing the current rates with those from previous investigations that found prevalences above $10 \%$, we observed a decrease in prevalence for A. lumbricoides, T. trichiura and hookworm to a level below 5\%. A decrease of the prevalence for schistosomiasis in schoolchildren to $8.6 \%$ was also observed, compared to previous investigations, which show prevalence rates between 15 and $40 \%$.

Some factors may be raised to explain such a drop in prevalence rates: (a) improvement of living conditions during the last 50 years $-39.4 \%$ of the study population are living in downtown having access to treated water and $20.1 \%$ of them having a sewage system in their residences; (b) some increase of knowledge about the transmission of helminth diseases (Diniz 2003); (c) a progressive diagnosis and treatment strategy for parasitic diseases performed by Funasa for more than 30 years and; (d) improved quality of the anthelminthic drugs with high cure rates and low side effects.

However, the presence of three intermediate host snail species in the region, B. tenagophila (Melo \& Pereira 1985), B. straminea, and B. glabrata (Massara et al. 2002), has been a permanent threat to schistosomiasis transmission, as the two latter species were found to be infected by the trematode. Such condition requires attention by health agents because, despite low prevalence rates of the disease, there is a high risk of schistosomiasis expansion. Other factors keep contributing to this expansion: poor sewage systems, spas with running water connected with water collections with snails, agricultural, leisure, and domestic activities associated with water contact.

Considering the understanding of the particularities regarding the factors and variables associated with schistosomiasis transmission in the region of Jaboticatubas, a multidisciplinary research team is planning control strategies together with the local population and regional political authorities in a sense of putting into praxis what was described by Barbosa (1987) that any scientific production is "cultural property and also a tool of work which shows social commitment".

An integrated control program is ongoing, based on health education activities and improvement of environmental conditions. It is aimed at reaching a wide range of local people support by continuing and sustaining those strategies in order to reach lower prevalence rates of the disease. A partnership with schools and the region Health Secretary, supported by the educative approach and critical pedagogy of Freire (1994), is based on a health education perspective that enables the construction of a transforming knowledge, committed to citizenship awareness (Massara \& Schall 2004).

Our results showed that an improvement of environmental conditions associated with water treatment and sewage system are not sufficient to control the disease in a short term, requiring complementary actions. Leisure activities, stream crossings, fishing, among other activities remain associated with schistosomiasis, which have demanded specific control strategies for this region with a higher support from the local population and health education strategies.

\section{ACKNOWLEDGEMENTS}

To José Geraldo Amorim da Silva for stool examination and to São José de Almeida community

\section{REFERENCES}

Barbosa CS 1987. Política de investigação no Brasil. Cad Saúde Pública 3: 343-51.

Barbosa C, Barbosa F 1998. Padrão epidemiológico da esquistossomose em comunidade de pequenos produtores rurais de Pernambuco, Brasil. Cad Saúde Pública 14: 129137.

Barbosa CS, da Silva CB, Barbosa FS 1996. Schistosomiasis: reproduction and expansion of the endemic region in Brazil. Rev Saúde Pública 30: 609-619. 
Brener Z, Mourão OG 1956. Inquéritos clínicos epidemiológicos em focos endêmicos de esquistossomose mansoni em Minas Gerais. Rev Bras Malariol Doen Trop 8: 519-526.

Bethony J, Willians JT, Kloos H, Blangero J, Alves-Fraga L, Buck G, Michalek A, Willians-Blangero S, LoVerde PT, Correa-Oliveira R, Gazzinelli A 2001. Exposure to Schistosoma mansoni infection in a rural area in Brazil. II: household infection factors. Trop Med Inter Health 6: 136-145.

Bethony J, Willians JT, Brooker S, Gazzinelli A, Gazzinelli MF, LoVerde PT, Correa-Oliveira R, Kloos H 2004. Exposure to Schistosoma mansoni infection in a rural area in Brazil. Part III: household aggregation of water contact behavior. Trop Med Intern Health 49: 381-389.

Cairncross S, Blumenthal U, Kolsky P, Maores L, Tayeh A 1996. The public and domestic domains in the transmission of disease. Trop Med Internat Health1: 27-34.

Carvalheiro JR1986. Processo Migratório e Disseminação de Doença. In Textos de Apoio de Ciências Sociais I, ENSP/ Abrasco, Rio de Janeiro.

CDS-Conselho de Desenvolvimento Social 1976. Programa Especial de Controle da Esquistossomose. Imprensa Oficial, Brasilia, DF.

Cury GC, Salles PGO, Reis MCW, Rego VM, Arndt AW, Souza Filho CBA, Moreira HB, Abreu MS, Leite PMG 1994. Prevalência da esquistossomose mansoni e de parasitoses intestinais em escolares da área rural do município de Jaboticatubas, MG, 1992-1993. Rev Soc Bras Med Trop 27: 217-220.

Dean AG, Dean JA, Burton AH, Dicker RC 1990. EPIINFO, version 6.04; a word processing data base and statistical program for epidemiology on micro computers. Centre of Disease Control, Atlanta, GA, US.

Diniz MCP 2003. As Representações Sociais da Esquistossomose de Escolares de Área Endêmica de Minas Gerais, MSc Thesis, Faculdade de Educação, UFNG, Belo Horizonte, 106 pp.

Enk MJ, Amorim A. Schall VT 2003. Acute schistosomiasis outbreak in the metropolitan area of Belo Horizonte, Minas Gerais: alert about the risk of unnoticed transmission increased by growing rural tourism. Mem Inst Oswaldo Cruz 98: 745-750.

Enk MJ, Caldeira RL, Carvalho OS, Schall VT 2004. Rural tourism as risk factor for the transmission of schistosomiasis in Minas Gerais State, Brazil. Mem Inst Oswaldo Cruz.

Freire P 1994. Pedagogia da Esperança: Um Reencontro com a Pedagogia do Oprimido, Paz e Terra, São Paulo.

Guimarães MDC, Lima e Costa MFF, Lima LB, Moreira MA 1985. Clinical-epidemiological study of schistosomiasis mansoni in schoolchildren of Ilha, Arcos District, Minas Gerais, Brazil, 1983. Rev Saúde Púb São Paulo 19: 8-17.

Husting EL 1983. Human water-contact activities related to the transmission of bilharziasis (schistosomiasis). J Trop Med Hyg 86: 23-35.

Katz N, Chaves A, Pellegrino J 1972. A simple device for quantitative stool thick-smear technique schistosomiasis mansoni. Rev Inst Med Trop São Paulo 14: 397-400.

Laurel AC, Gil JB 1975. Morbidad, ambiente y organización social: modelo teorico para el analises de la enfermedad en el medio rural. Salud Publica Méx 17: 471-478.

Lima e Costa MFF 1983. Estudos Clínico-epidemiológicos da
Esquistossomose Mansoni em Comercinho, Minas Gerais (1974-1981), PhD Thesis, Departamento de Clínica Médica da Faculdade de Medicina da UFMG, Belo Horizonte.

Loureiro S 1989. Social aspects of the epidemiology and control of schistosomiasis mansoni. Mem Inst Oswaldo Cruz. 84: 124-133.

Massara CL, Schall VT 2004. A pedagogical approach of schistosomiasis - an experience in Health Education in Minas Gerais, Brazil. Mem Inst Oswaldo Cruz (in press).

Massara CL, Carvalho OS, Caldeira RL, Janotti-Passos LK, Schall VT 2002. First report on the presence of Biomphalaria straminea in the municipality of Jaboticatubas, State of Minas Gerais, Brazil. Mem Inst Oswaldo Cruz, 97 (Suppl. I): 27-29.

Melo AL, Pereira LH 1985. On the finding of Biomphalaria tenagophila naturally infected with Schistosoma mansoni in the state of Minas Gerais, Brazil. Rev Inst Med Trop São Paulo 27: 99-101.

Moza PG, Pieri OS, Simões Barbosa C, Rey L 1998. Fatores sócio-demográficos e comportamentais relacionados à esquistossomose em uma agrovila da zona canavieira de Pernambuco, Brasil. Cad Saúde Pública 14: 107-115.

Paraense WL 1975. Estado atual da sistemática de planorbídeos brasileiros. Arq Museu Nac Rio de Janeiro 55: 105-128.

Pellon AB, Teixeira I 1950. Distribuição Geográfica da Esquistossomose Mansônica no Brasil, Divisão de Organização Sanitária, Rio de Janeiro.

Ruiz JM 1952. Contribuição ao estudo das formas larvares de trematódeos brasileiros. 3. Fauna de Belo Horizonte e Jaboticatubas, Estado de Minas Gerais. Mem Inst Butan$\tan 24: 45-62$.

Silva AAM, Cutrim RNM, Alves MTSSB, Coimbra LC, Tonial SR, Borges DP 1997. Water contact patterns and risk factors for Schistosoma mansoni infection in a rural village of Northeast Brazil. Rev Inst Med Trop São Paulo 39: 91-96.

Souza CP, Drumond SC, Silva JCE, Queiroz LA, Guimarães CT, Rocha RS 1998. Investigação sobre a transmissão da esquistossomose no complexo turístico da Serra do Cipó, MG. IESUS VI: 43-51.

Souza MSL, Carvalho OS, Souza DWC, Massara CL, Araújo RL, Paulino NMS, Ribeiro MJA, Oliveira FC, Nogueira JN, Chaves TE, Bayão Jr E, Assis RL 1988. Inter-relação entre parasitoses e hipovitaminose A. Infecção por Schistosoma mansoni e o nível sérico de retinol de população de zona endêmica de Minas Gerais (Brasil). Rev Inst Med Trop São Paulo 39: 281-287.

Stata Corporation 2001. Stata statistical software [computer program]. Release 6.0. College Station, Texas, United States: Stata Corporation.

Vidigal THDA, Spatz L, Nunes DN, Simpson AJG, Carvalho OS, Dias Neto E 1998. Biomphalaria spp. Identification of the intermediate snail host of Schistosoma mansoni by polymerase chain reaction amplification and restriction by polymerase chain reaction amplification and restriction enzyme digestion of the ribosomal RNA gene intergenic spacer. Exp Parasitol 89: 180-187.

Watts S, Khallaayoune K, Bensefia R, Laamrani H, Gryseels B 1998. The study of human behaviour and schistosomiasis transmission in an irrigated area in Moroco. Social Sci Med 46: $755-765$. 